\title{
Mushroom: A Panacea for Cancer
}

\section{Prakash S Bisen*}

School of Studies in Biotechnology, Jiwaji University, Gwalior 474010, India

The globalization has made world flat, at least, as far as epidemiological profiles are concerned, non-communicable diseases like cancer, diabetes which were a typical hallmark of developed countries are now prevalent even in less developed countries. Around $64 \%$ of all cancer deaths are reported from less developed countries $[1,2]$. Cancer death rate in developed countries like US has started to decline owing to the technological advancements and health care infrastructure evolved over several decades [2,3]. However, same results cannot be expected from lesser developed countries with bare minimum health care infrastructure, mainly designed to control host of communicable diseases like HIV, tuberculosis. The adaptation of globalized lifestyle in lesser developed countries, which are already struggling with communicable diseases, have caused double whammy in from of emergence of chronic non-communicable diseases like cancer, diabetes etc [1].

The management of cancer still depends heavily on the use of chemotherapeutic compounds, which literally drains vitality out of cancer patient, because of its unavoidable side effects due to nondiscriminatory killing of normal cells. Targeted therapies can address issues arising out of non-specific action of chemotherapeutic drugs however their success is dependent on presence of specific genetic profile in cancer patient. Targeted therapies are now developed as a companion kit which helps to select patient with right genetic profile, thus avoiding patients who may not be benefited as intended. Targeted therapies although promising and effective are often very expensive, making it a nonviable treatment option in countries with scarce financial resources. Healthcare strategies focused around development and promotion of safe, potent and cost-effective anti-cancer drugs is the need of the hour in less developed countries [4].

Numerous compounds from natural sources have found its way to become anti-cancer drugs with/without structural optimization $[5,6]$. Through this brief write-up I want to highlight anti-cancer role of mushrooms. The mushrooms with anti-cancer activity belong to the genus Ganoderma, Agaricus, Cordyceps, Calvatia, Fomes, Phellinus, Inonotus, Pleurotus, Funlia, Clitocybe, Antrodia, Trametes, Xerocomus, Schizophyllum, Flammulina, Suillus, Inocybe, Lactarius, Lentinus and Russula. We can expect more of them to be added in this list since many mushrooms are not yet identified. The bioactive compounds isolated from mushrooms with an anti-tumor activity are either water soluble $\beta$-D-glucans, $\beta$-D-glucans with heterosaccharide chains of uronic acid, galactose, mannose and xylose or $\beta$-D-glucanprotein complexes (proteoglycans) [7-10]. The compounds from mushrooms have shown quite promising anti-cancer activity in various studies. Thanks to some of the recent studies, we have now better understanding of the mechanism of action of anti-cancer compounds extracted from mushrooms. Nevertheless, larger clinical studies would be required to test their efficacy and safety profile. Dedicating drug discovery efforts focused around compounds from natural sources like mushroom would be best strategy for less developed nations who cannot afford traditional route of drug discovery which requires huge investment [11-15].
"Mushrooms" is a famous poem by Sylvia Plath [16], which is a one of the masterpiece written by her, has been subjected to the range of interpretations which are only limited by analyst's imagination. Various literary analysts have regarded mushroom in this poem as a symbolic figure representing anything which goes unnoticed or neglected in the society with aspirations to eventually find its deserved place. The realization of medicinal potential of mushrooms surprisingly followed similar trend, its role as an anti-oxidant, anticancer, anti-inflammatory, immunomodulator has got global acceptance now compared to earlier times when knowledge about its medicinal use was confined to oriental medicines, in fact until recently they were widely considered as 'forbidden fruit'. Next time when you look at mushrooms out in nature or supermarkets racks, do consider them beyond an ingredient of a culinary delicacy, as a miniaturized non-profit making pharmaceutical factory churning out invaluable medicinal compounds to treat malignancies like cancer.

\section{References}

1. Bisen PS, Khan Z, Bundela S (2013) Biology of Oral Cancer - Key Apoptotic Regulators. CRC Press, pp292.

2. Bisen PS (2012) Enabling Oral Cancer Translational Research in India. $J$ Cancer Sci Ther 4: i-i. doi:10.4172/1948-5956.1000e103.

3. Ferlay J, Shin HR, Bray F, Forman D, Mathers C, Parkin DM (2010) GLOBOCAN 2008 v2.0, Cancer Incidence and Mortality Worldwide: IARC CancerBase No 10 [Internet]. Lyon, France: International Agency for Research on Cancer.

4. Siegel R, Naishadham D, Jemal A (2013) Cancer statistics, 2013. CA Cancer $\mathrm{J}$ Clin 63: 11-30

5. Bisen PS (2012) Marine Microbes: Unexplored Therapeutic Bio-mine. J Cance Sci Ther 4: xviii-xix. doi:10.4172/1948-5956.1000e112.

6. Bisen PS, Bundela SS, Sharma A (2012) Ellagic Acid - Chemopreventive Role in Oral Cancer. J Cancer Sci Ther 4: 023-030.

7. Song FQ, Liu Y, Kong XS, Chang W, Song G (2013) Progress on understanding the anticancer mechanisms of medicinal mushroom: inonotus obliquus. Asian Pac J Cancer Prev 14: 1571-1578.

8. Suarez-Arroyo IJ, Rosario-Acevedo R, Aguilar-Perez A, Clemente PL, Cubano LA, et al. (2013) Anti-tumor effects of Ganoderma lucidum (reishi) in inflammatory breast cancer in in vivo and in vitro models. PLoS One 8: e57431.

9. Wu H, Tao N, Liu X, Li X, Tang J, et al. (2012) Polysaccharide from Lentinus edodes inhibits the immunosuppressive function of myeloid-derived suppressor cells. PLoS One 7: e51751.

10. Radwan FF, Perez JM, Haque A (2011) Apoptotic and Immune Restoration

*Corresponding authors: Prakash S Bisen, School of Studies in Biotechnology, Jiwaji University, Gwalior 474010, India, E-mail: psbisen@gmail.com

Prakash S Bisen, Center for Innovative Technology, Vikrant Institute of Technology and Management, Gwalior 474005, India, E-mail: psbisen@gmail.com

Received August 27, 2013; Accepted August 28, 2013; Published August 30 2013

Citation: Bisen PS (2013) Mushroom: A Panacea for Cancer. J Cancer Sci Ther 5 e125. doi:10.4172/1948-5956.1000e125

Copyright: $\odot 2013$ Bisen PS. This is an open-access article distributed under the terms of the Creative Commons Attribution License, which permits unrestricted use, distribution, and reproduction in any medium, provided the original author and source are credited. 
Effects of Ganoderic Acids Define a New Prospective for Complementary Treatment of Cancer. J Clin Cell Immunol S3: 4.

11. Bisen PS, Baghel RK, Sanodiya BS, Thakur GS, Prasad GB (2010) Lentinus edodes: a macrofungus with pharmacological activities. Curr Med Chem 17 2419-2430.

12. Sanodiya BS, Thakur GS, Baghel RK, Prasad GB, Bisen PS (2009) Ganoderma lucidum: a potent pharmacological macrofungus. Curr Pharm Biotechnol 10: 717-742.

13. Chen S, Xu J, Liu C, Zhu Y, Nelson DR, et al. (2012) Genome sequence of the model medicinal mushroom Ganoderma lucidum. Nat Commun 3: 913.
14. Feng L, Yuan L, Du M, Chen Y, Zhang MH, et al. (2013) Anti-Lung Cancer Activity through Enhancement of Immunomodulation and Induction of Cel Apoptosis of Total Triterpenes Extracted from Ganoderma luncidum (Leyss. ex Fr.) Karst. Molecules 18: 9966-9981.

15. Wang CL, Pi CC, Kuo CW, Zhuang YJ, Khoo KH, et al. (2011) Polysaccharides purified from the submerged culture of Ganoderma formosanum stimulate macrophage activation and protect mice against Listeria monocytogenes infection. Biotechnol Lett 33: 2271-2278.

16. Plath Sylvia (1977) “The Colossus and Other Poems”. Faber and Faber 